Georgia State University

ScholarWorks @ Georgia State University

Middle and Secondary Education Faculty

Publications

Department of Middle and Secondary Education

2017

\title{
Learning Language and Vocabulary in Dialogue with the Real Audience: Exploring Young Writers' Authentic Writing and Language Learning Experiences
}

\author{
Ewa McGrail \\ Georgia State University \\ J. Patrick McGrail \\ Jacksonville State University \\ Alicja Rieger \\ Valdosta State University
}

Follow this and additional works at: https://scholarworks.gsu.edu/mse_facpub

Part of the Curriculum and Instruction Commons, and the Junior High, Intermediate, Middle School Education and Teaching Commons

\section{Recommended Citation}

McGrail, Ewa; McGrail, J. Patrick; and Rieger, Alicja, "Learning Language and Vocabulary in Dialogue with the Real Audience: Exploring Young Writers' Authentic Writing and Language Learning Experiences" (2017). Middle and Secondary Education Faculty Publications. 108.

https://scholarworks.gsu.edu/mse_facpub/108

This Book Chapter is brought to you for free and open access by the Department of Middle and Secondary Education at ScholarWorks @ Georgia State University. It has been accepted for inclusion in Middle and Secondary Education Faculty Publications by an authorized administrator of ScholarWorks @ Georgia State University. For more information, please contact scholarworks@gsu.edu. 
Learning Language and Vocabulary in Dialogue with the Real Audience: Exploring Young Writers' Authentic Writing and Language Learning Experiences

Ewa McGrail, J.P. McGrail and Alicja Rieger

\section{Abstract}

Purpose

To explore the potential of conversations with an authentic audience through blogging for enriching in the young writers the understanding of the communicative function of writing, specifically language and vocabulary use.

\section{Design}

We situate our work in a language acquisition model of language learning where learners develop linguistic competence in the process of speaking and using the language (Krashen, 1988; Tomasello, 2005). We also believe that language learning benefits from formal instruction (Krashen, 1988). As such, in our work, we likened engaging in blogging to learning a language (here, more broadly conceived as learning to write) through both natural communication (acquisition) and prescription (instruction), and we looked at these forms of learning in our study.

We were interested in the communicative function of language learning (Halliday, 1973; 1975; Penrod, 2005) among young blog writers as we see language learning as socially constructed through interaction with other speakers of a language (Tomasello, 2005; Vygotsky, 1978), .

\section{Findings}

The readers and commenters in this study supported young writers in their language study by modeling good writing and effective language use in their communication with these writers. Young writers also benefited from direct instruction through interactions with adults beyond classroom teachers, in our case some of the readers and commenters.

Practical Implications

Blogging can extend conversations to audiences far beyond the classroom and make writing an authentic endeavor for young writers. Teachers should take advantage of such a powerful tool in their writing classrooms to support their students' language study and vocabulary development.

Keywords: Blogging, Language Study, Vocabulary Development, Young Writers; Writing 


\section{Introduction}

Language study and vocabulary development are essential components of learning to read and write (Kirby, Kirby \& Liner, 2004; Calkins, 1994). The vivid use of language and vocabulary makes writing insightful and compelling and communication becomes effective and intentional. In contrast, poor grammar, word choice and punctuation interfere with communication; a weak vocabulary in particular impacts reading comprehension (Graves, 2000). Incorrect word choice can be embarrassing, while the use of vague or bland words may bore the reader. Simply put, language and vocabulary matter (Bruffee, 1994; Dunn \& Lindblom, 2011; Elbow, 1998). Successful writers know that. They use language and words carefully and they enjoy studying language and vocabulary rules and usage (Kittle, 2008; Dunn \& Lindblom, 2011).

Young writers, however, find grammar and vocabulary difficult to learn and enjoy (Andrews \& Smith, 2011; Weaver, 1998). They also find the study of these skills of little value and application to life (Gilbert \& Graham, 2010). This is because they often learn language and vocabulary in a mechanistic or automated way through "fill in the gaps" or multiple choice activities. Freeman and Freeman (2004) agreed when they captured the state of language instruction in schools in these words:

[E]ven though language is a fascinating topic, the only exposure many students get to language study during their elementary and secondary years is worksheets and exercises that bore them to tears and serve little practical purpose in improving their reading and writing (p. xi).

They thus learn grammar and vocabulary in abstraction, that is, (in isolation from the communicative context and purpose for which they are intended (Applebee \& Langer, 2011; Gilbert \& Graham, 2010; Weaver, 1998)). Research has found, however, such instruction to be ineffective, having little effect on the quality of student writing (Graham, Harris, \& Santangelo, 2015). In response to this situation, Freeman and Freeman (2004) suggest that "what students need is a new approach" (p. xi) to language study.

We contend that teaching young writers strong language use and vocabulary through dialogue with actual readers of student writing on blogs is an innovative approach to language study that can change this undesirable situation. Accordingly, this chapter demonstrates the potential of writer-reader conversations for enriching in the young writer the understanding of the communicative function of writing, specifically language and vocabulary use. The chapter draws from a year-long study of fifth-graders writing for and with an authentic audience, that is, the readers of their blog posts. The chapter concludes with practical recommendations for enhancing authentic writing and language learning experiences in the classroom.

\section{Literature Review}

Much of the literature that we reviewed concerning language study among young writers focused on morphological awareness and vocabulary skills. We synthesize the key findings from this literature here and make connections to our study. 


\section{Morphological Awareness}

Morphological awareness refers to children's ability to recognize the structural morphemes or functional constitutive parts of words, and manipulate them to create fresh composition (Kirby, et al., 2012). An example might be that of a child who intuitively recognizes what the word playful means, even if she has never encountered the word in that exact form. She "back-intuits" that it must describe, as indeed it does, something that is "full of play," as she recognizes the word play, and the morpheme "ful" that is a shortened version of "full." Research has long suggested that explicit and direct instruction in morphological awareness can have positive effects of on improving student reading comprehensions skills, especially reading complex texts, advancing their spelling and vocabulary development, as well as enhancing the quality of their writing skills (Goodwin \& Ahn, 2010; Kieffer \& Lesaux, 2010; Kieffer \& Lesaux, 2012; Kuo \& Anderson, 2006; Pacheco \& Goodwin, 2013).

Some scholars argue however, that "most language learning happens naturally, without conscious effort" (Carlisle, 2010, p. 465) and that "[m]orphological awareness develops gradually, as students come to understand complex relations of form and meaning" (Carlisle, 2010, p. 466). These scholars question the need for and effectiveness of explicit and direct instruction in morphological awareness. For instance, Carlo et al. (2004) who examined the effectiveness of 15-week intervention that consisted of the use of direct instruction while teaching words and specific word learning strategies with a morphology awareness element discovered "only marginally significantly differential gains" (p. 196) for both English Language learners and their native English-speaking peers. However, Kirby, et al. (2012) found that "morphological awareness was a significant predictor of word reading accuracy and speed, pseudoword reading accuracy, text reading speed, and reading comprehension" in children from grades 1 through 3 (p. 389).

\section{Vocabulary Development}

With regard to vocabulary development, research provides strong support for explicit and systematic approaches to teaching vocabulary skills (Beck, Perfetti, \& McKeown, 1982; Kame'enui, Carnine, \& Freschi, 1982). For instance, Marulis and Neuman (2010), in their metaanalysis of 67 studies for the impact of direct instruction on acquisition of vocabulary skills, reported significant gains on vocabulary measures (an effect size of .88). Explanation of words and providing examples were found particularly effective forms of explicit vocabulary instruction. At the same time, research offers evidence in support of informal approaches to teaching vocabulary in the classroom as well. This is because as Seipel (2011) contends, "a substantial amount of vocabulary is learned incidentally from context" and that informal instruction "is able to fill the instructional void left by inadequate time in classrooms for explicit vocabulary instruction" (p. 7).

In summary, while the findings acknowledge the positive role of formal and direct instruction, they also suggest substantial benefits of informal and non-traditional approaches as well. We also note that despite the benefits of traditional approaches to language study, young writers find learning grammar and vocabulary out of context and through mindless repetition uninteresting and ineffective (Andrews \& Smith, 2011; Weaver, 1998 (Applebee \& Langer, 
2011; Gilbert \& Graham, 2010; Weaver, 1998). Our study among fifth-graders explored the potential of blogging when it was done with an authentic purpose and with real audiences.

\section{Conceptual Framework}

\section{Methodology}

We draw on multiple perspectives to inform our work, broadly situating it in a language acquisition model of language learning where learners develop linguistic competence in the process of speaking and using the language (Krashen, 1988; Tomasello, 2005). According to the language acquisition theory, language learning involves acquiring knowledge of language as a system with subsystems such as phonology, morphology, syntax, semantics and pragmatics (Krashen, 1988; Tomasello, 2005). Speakers of a language use "the full range of the subsystems" when they speak or write (Harmon \& Wilson, 2006, p.12). While the language learning process is aided by what Noam Chomsky (1965) referred to as the language acquisition device (LAD), which is activated through exposure to the language amid a rich linguistic context, it is also benefited by formal instruction (Krashen, 1988). In other words, rich language learning is comprised of both conscious and unconscious knowledge attainment, that is, acquisition through natural communication and learning through prescription.

Blogging with an authentic audience serves as a rich linguistic learning context, as it provides young writers with opportunities to observe language use in the context of writing produced by expert writers (readers and commenters). In addition, the feedback that young blog writers receive from their readers and commenters in response to their writing is a form of instruction itself about various aspects of their language and vocabulary use (e.g., grammar, syntax, and word choice) and the communicative effectiveness of these choices. As such, in our work, we likened engaging in blogging to learning a language (here, more broadly conceived as learning to write) through both natural communication (acquisition) and prescription (instruction).

We also view language learning as socially constructed through interaction with other speakers of a language, particularly adults and more knowledgeable others (Tomasello, 2005; Vygotsky, 1978). It is through the social interaction with others that language users learn about the functions and uses of languages within specific discourses, disciplines, communities, and contexts (Gee, 1990). In addition, the socially-constructed learning process in which they engage with other speakers helps young learners to understand and appreciate the relationships between language and intention, connotation and denotation, as well as overt and covert meanings (Harmon \& Wilson, 2006). This is because speakers and writers make the choice of syntax and words, and use other simultaneous semiotic means of representation, such as signs, images, or symbols, to enable them to accomplish specific rhetorical goals (Ede \& Lunsford, 1984; Lunsford \& Ede, 2009). Given this understanding of language learning, in our work, we were interested in the communicative function of language learning (Halliday, 1973; 1975; Penrod, 2005) among young blog writers. 


\section{Data Collection}

The data set for this study consisted of elementary student writing generated in a yearlong blogging project in a fifth-grade language arts classroom in a Title I school, and their readers' comments and responses, for a total of 659 single-spaced pages of blog scripts. The blog writing the students produced included personal narratives, in which students chose topics to describe themselves and their interests to their readers; persuasive writing, in which students were asked to write convincingly about a subject about which they themselves felt a conviction; and research reports, where students shared with their audiences the readings in content area that were of particular interest to them. Much of this writing, however, consisted of "free writes" and quick posts to either invite response from readers or to respond to comments they had received from audience members. The audience of readers came from many walks of life and parts of the world and frequently conversed textually with these young writers. At the start of the project, we solicited audience members from the national and international educational and blogging professional communities to which we belonged. These audience members were contacted because they either maintained classroom blogs or posted regularly on educational blogs. Many retired teachers and other teachers to whom we introduced the project and explained its educational goals volunteered to read and comment on student blogs. We also recruited graduate students enrolled in teacher education programs at our institutions. We explained the goals of the blogging project and we asked the readers and commenters to assist young writers in developing critical thinking and writing skills. Other respondents and commenters were members of the audience at large who joined the existing conversations. We had a system in place allowing us to monitor incoming comments from readers and block inappropriate comments or commenters from posting on student blogs, if needed.

The teacher maintained a class blog that introduced students to blogging and its conventions, and included strategies and advice on how to develop and sustain dialogue in posts and comments, how to ask and answer questions, and how to develop voice in one's writing. Student blog writers were also mentored about internet ethics, that is, how to communicate in respectful and responsible ways with these larger audiences and how to employ public writing conventions, such as giving credit to others' words and not revealing personally identifying information. The class blog also provided topics for future conversations and communication with readers and commenters.

The student writers we studied were a group of ten girls and five boys - nine Caucasian, five Hispanic, and one African-American. Two students were in the gifted program and one was in the special education program. All students were new to blogging and needed to work on critical thinking and writing skills. The group reflected the school student population's ethnic and socioeconomic backgrounds, with $81 \%$ considered economically disadvantaged, based on student participation in free or reduced lunch program. (This information was obtained from the school website).

\section{Data Analysis and Limitations}


We employed a qualitative content analysis method (Creswell, 2007) to develop a coding scheme that included open and axial coding (Corbin \& Strauss, 2008). This helped us to explore patterns in the data about vocabulary development and various aspects of language study in student writing. These patterns included categories such as inquiries about language and vocabulary use; spelling, grammar and punctuation interventions; strategies for engaged writing; teaching new vocabulary; modeling language use; and cultural and idiosyncratic differences in language and vocabulary applications. The acquisition model of language learning (Krashen, 1988; Tomasello, 2005) and the socio-cultural perspective on the meaning making process (Tomasello, 2005; Vygotsky, 1978) informed the analysis and description of the findings reported in this work. The data were analyzed iteratively by the lead author and in consultation with the other authors, who provided an audit check (Creswell, 2007) for the initial analysis. This collective data analysis process resulted in adjustments made to the open and axial coding and reduction of the coding categories to two themes which are reported in the findings, one focusing on the vocabulary development and another on key aspects of language study.

Although there is much that can be gleaned from the blog writing of these young writers about their individual and collective language learning and vocabulary development experiences, there is a limit to what can be learned from written product analysis (Dalton \& Smith, 2014). Future studies should engage young writers in other forms of reflection and meta-analysis of their own writing to access the student writer perspectives on their language study learning experiences.

Note: we use pseudonyms for student bloggers and respondents in our data reporting. We also preserve the numerous idiosyncratic spellings of our young authors and their respondents.

\section{Findings}

\section{Learning Vocabulary and Language Use through Immersion/Acquisition}

The student bloggers in this study were exposed to good writing and had numerous opportunities to observe and be immersed in effective language use by experienced writers. For example, in the following response to blogger Michael's story about Yoshi (a character in his fictional story), his commenter used a new word, "aghast," to describe her reaction to Michael's unusual choice of the phrase "concentration camp" for his story about a learning camp. Michael's story began with these words, "My post today is about Yoshi. They go to a learning camp called concentration camp. They learn school stuff and they learn about Yoshi stuff.....":

Hi Michael, When I first read your post I was aghast! I immediately thought of one definition of concentration when you said a learning camp was a concentration camp. Then I got to thinking and realized maybe Yoshi's meaning was different from what I first thought. Can you tell me what meaning concentration has when it's used for Yoshi's learning camp? Can you imagine why I might have been aghast?...

Best,

Lena 
Another commenter, who also wondered about the unusual use of this phrase, provided a clue to the meaning of the word "aghast" in the question she posed to Michael: "Can you find out why I was startled by your reference to a concentration camp?"

Alternatively, Chara modeled for Anni how to pull in the reader with an engaging introduction to the story:

Have you thought of starting your story more dramatically? Something like "Isabelle had always dreamed of climbing Cir Mhor [that's the name of the left-hand mountain]. Today, at last, she was on her way. The mud squelched beneath her feet and water trickled into her boots, but she didn't care." That's how I feel in that particular glen - it's like a muddy paradise as far as I'm concerned!

Dulce Maria, in turn, received this sophisticated response, which introduced her to complex syntax and specialized vocabulary concerning a tree saving call she made to the readers and commenters on her blog:

Hi Dulce Maria, Reading your comment, I kept thinking of the Amazons, the so-called lungs of our planet, which are threatened by an incessant deforestation campaign by some "strong" corporations. I do agree with you that the consequences of cutting threes without replacing them will cost us not only changes in ways/quality of living, but also have us live a future without animals. I can't agree more with your ideas and the urgent need we have to take action soon. I was just wondering what actions could each of us take to raise others' attention to this problem. Most people are too busy to be thining of a future without trees and animals; they have to be reminded of the need to stop cutting trees and start using alternatives. Do you have any ideas for action?.... Omer

Another blogger, Eddie, was introduced to phi, a complex mathematical concept, by his commenter, a high school math teacher. The teacher even offered an exercise for Eddie so that he could try out the application of the concept to real life situations, such as in how to measure the distance between certain body parts:

There's another special number called "e" and another one called phi (like "fly" without the "I").

Phi is approximately 1.618 which seems weird I know, but it gets weirder. If you measure your height and then the distance from the ground to your belly button, then divide your height by the belly button distance it's going to be pretty close to 1.618. Measure the length of your arm (shoulder to finger tips), then measure from your elbow to your finger tips. Divide the long length by the short one ... you'll get 1.618 (Phi) again. In addition, the commenters and readers often modeled for our young writers the use of colorful language, rich descriptions, and engaging dialogue in their own writing, as evident in this sample of prose by Victoria's commenter, who responded to Victoria's call to the readers to tell their own stories in support of wildlife, especially polar bears:

Hi Victoria,

This post made me think about another story I read in the news the other day.

A 6-year-old, towheaded neighbor, George, came screaming through the front door of this lady's house. "The polar bear is getting extinct," he yelled. "It's global warming. It's killing them." 
The lady telling the story said her children had been talking about how the melting Arctic ice cap is reducing the bears' hunting ground, and attempts at swimming to catch seals have only led to increased drowning. Deaths are up, and the main culprit, say experts, is global warming.

This lady's son told the six-year old neighbor "That's why we're getting our new car," my 6-year-old son explained to George, his best friend. "To save the polar bear."

This is how the lady explained her son's reasoning:

"As counterintuitive as it sounded, my son's statement was true. Global warming was the main factor in deciding to buy a fuel-efficient car when we traded in our minivan this holiday. For our children, that translated into helping the polar bear."....

Mrs. C

\section{Learning Vocabulary and Language Use through Instruction}

Learning about vocabulary and language use among young writers in this study was also supported with direct instruction. Direct instruction was provided by readers and commenters and it concerned various aspects of language use and vocabulary development. Specifically, readers and commenters introduced student bloggers to new vocabulary. Providing a definition, synonym, illustration or paraphrase were the most frequent strategies that the commenters employed to accomplish this goal. For example, Cordelia introduced Anni to two new verbs, to persuade and to eliminate [in bold], in her response to Anni's post urging schools to allow water fountains on their premises. Cordelia also was brainstorming with her the ways in which she could bring forth her proposal to fruition:

What a fabulous idea! I had never even thought about having a water fountain right there on the playground. That would solve so many problems. You stated your reasons in a very organized and persuasive way. (Persuasive means you are trying to get someone else to agree with you.) It is obvious you had thought this out before posting.... So, you could add to your very good points about thirst and good health that an outside water fountain would also eliminate (get rid of) hallway misbehavior. Has your principal read your opinion on a playground water fountain? Do you think he/she would agree? Have you thought about making an appointment with the principal and presenting your persuasive speech? Think about it. Students often bring about the best changes. If you don't, who will?

A commenter from Australia, on the other hand, taught Anni not only another word for water fountains (bubblers) but also explained that the rules concerning the use of water fountains can vary across different contexts and different climates:

In Queensland, Australia where I teach and went to school, water fountains (bubblers) are an essential! Each school has rows of bubblers outside for student use. It gets so hot here and much of our time is spent outdoors that i needed to be reminded by your entry that not all schools have the same needs. Children are strongly encouraged to drink water often at school (in and out of the classroom). I taught in Canada for a year in 1999 and was really surprised by how little water people consumed there in a day. Of course the difference in climate impacts on this. 
Alternatively, the readers and commenters probed young writers' about the use of vocabulary in their own writing. To illustrate, in this post, the commenter wanted Johnny to clarify the meaning of "Runescape": I am a little confused about what Runescape is" and she wondered if rewriting the passage with the confusing content could help: "Do you think you could maybe think about how you have written the middle part of this and see if you can make it any clearer? Then maybe I'd understand better. :" Although Johnny was willing to provide an explanation "Runescape is just a online game that teaches you normal skills," he did not feel a rewrite was necessary.

In addition, the readers and commenters encouraged young writers to use descriptive language and to elaborate on their ideas. For example, one commenter asked Mia to explain why she chose the adjective "peace" to describe a picture with a snowed-in house in it. Mia was happy to provide this explanation:

I chose peace becuase when first you look at it. It looks white, calm, and like you will like to really want to play on it. But if you think about it and look at it again you might think of more adjectives.

In yet another example, Cordelia posed this question to Michael, a student blogger who had written an amusing story about his dog, named Sparky: "Don't you just love those sad "please pet me" eyes of a lab?" Michael was happy to supply the answer and elaborate on it as well: "My dog does the please pet me eyes to and when I am on the computer she sticks her head through the armrest and pushes my arm on her head."

Many comments focused on various aspects of language use in student blog writing, including grammar, punctuation or spelling. For example, this commenter was helping Anni to see the difference in meaning between "their" and "there," the two words she used in her post about a family camping trip which she entitled "Mountain Sight:"

I like the ending of your story! I think there are some mistakes you can find by proofreading your paper out loud. Also, figure out the difference between homophones so you know you are using the right one. For example, there and their are different words. Can you tell me when you would use each one?

Anni did her homework and offered this explanation in response to her commenter, "You would use their when it belongs to someone and you would use there when it is talking about some where." Cordelia, on the other hand, offered this advice to Rosalinda on the meaning, spelling and pronunciation of a word she needed to describe one of her family members in her post, "Sister in Sight:"

How very exciting! It sounds like you had TWO wonderful things come your way - a visit from your sister and a chance to be with your nephew Jonathon! A nephew is what you call your brother or sister's son. A niece is what you call your brother or sister's daughter. So, you would say that Jonathon is your nephew (pronounced like "nefew"). The "ph" makes the "f" sound.

Another commenter encouraged Mary to adapt a different approach to creating the mood in her story than through the use of the exclamation mark, "Can I suggest that instead of using multiple exclamation marks you use your language skills (which are considerable) to create the tone of voice implied?" Mary accepted the challenge and promised to take it into consideration in her future stories: "I will take your advice and stop using so many exclamation marks." Alternatively, Lena, another commenter, tried to convince Johnny that spelling matters 
when she challenged his spelling of his favorite instrument [gautier] in the post he entitled "What are you passionate about":

Hi Jhonny,

You really are passionate about music! It comes through when you describe all you do with music and your guitar. I agree hard work comes with passion but don't you feel great when you look at all you accomplish?

One question: I wonder if you might want to check the spelling of guitar. Shouldn't a man such as yourself with such a passion for his instrument spell it correctly? Best, Lena

Although Johnny agreed with Lena, he admitted that he found the word difficult to spell, in his playful reply back to Lena: "I know but i always get it mixed up with the spelling of my instrument. But i can play it does that matter better then the spelling it?" Victoria, another, student blogger, too learned about the importance of punctuation when she received this response to her post "What is our main resources," because it was missing a full stop:

Something that makes our writing clear is our use of punctuation. Can you see places in this post where you have run sentences together? Look at your very first sentence and see if you can spot where there should be a full stop. Then you can check the rest of the post.

I'm very, very fussy about punctuation because I like clarity in writing!

\section{Discussion and Implications}

\section{Learning Vocabulary and Blogging}

Learning vocabulary requires seeing and using new words in rich contexts (Stahl \& Fairbanks, 1986; Marulis \& Neuman, 2010). Analogous to learning new words through reading, students need to be provided with opportunities to apply them to new contexts, including their own writing (Carter \& Evensen, 2011). As evident in this work, blogging provided such opportunities both when students wrote about their learning that involved new concepts and when they invited the use of new terminology to describe their learning. Readers introduced bloggers to new ideas and specialized vocabulary.

As students blogged about ideas interesting to them individually, they were involved in deeper processing and learning of these words (Stahl \& Fairbanks, 1986). More importantly, they often received feedback from their readers and commenters, confirming the correctness or signaling the issue with their usage and indicating how to fix it, the process itself serving as "new instruction, rather than informing the student solely about correctness" (Kulhavy, 1977, p. 212). Vocabulary development through blogging in our work with the young writers thus depended on active and contextualized engagement with new words (Padak, Newton, Rasinki, \& Newton, 2008).

Young writers also benefited from teaching through interactions with adults beyond classroom teachers, in our case some of the readers and commenters. Specifically, these commenters, about whom we knew little (because they were an unselected "real world" group) appeared to be a combination of undergraduate and graduate students, teachers and retired teachers, based on their limited self-description. They often asked for clarification of specific 
words in the students' writing or introduced them to new vocabulary in their comments and responses. Because they were from different countries, they also educated the young writers about the difference in word choice and usage across cultures and linguistic contexts. As such, the young writers were learning vocabulary in an ideal communicative context (Applebee \& Langer, 2011; Gilbert \& Graham, 2010; Weaver, 1998). More importantly, they had the opportunity to discover for themselves that there is more than looking up new words in the dictionary to learn their meanings. The context and the readers' background on a given subject matter, too.

\section{Language Study and Blogging}

The readers and commenters in this study supported young writers in their language study by modeling good writing and effective language use in their communication with these writers. As such, their responses to student blogging served as exemplars for these young writers.

In light of the genre theory, the writing samples served as "the functional model of language, revealing the way in which a particular culture manages to coordinate different and recurrent language resources to construct particular meanings that are valued within the specific cultural context" (Cao \& Guo, 2015, p. 2613). These writing samples thus taught the young writers in this study about the communicative purpose and function of language and about the rhetorical tools and strategies that were available to them in support of their own rhetorical and communicative goals (Halliday, 1973; 1975; Penrod, 2005).

Such subtle and enriching goals have not always been supported in contemporary American writing practice in schools. Recent studies have shown that the most frequent writing assignments involved completing worksheets and writing short responses, as opposed to writing for a real-life purpose and an authentic audience (Applebee \& Langer, 2011; Gilbert \& Graham, 2010). Our rich international blogging investigation has shown promise in overcoming some of these challenges by providing young writers with real world counterparts and sympathetic foreign English language practitioners with whom to negotiate meaning and structure.

Another way the readers and commenters supported young writers in improving their writing craft was through direct instruction on the matters of language use in their blog writing. As evident in our data, the purpose of such instruction was not merely to help the young writers fix language issues in their writing such as run-ons, fragments, misused words, bland prose, grammar, punctuation and spelling mistakes but also to help them understand how these problems affect the readers and interfere with comprehension (Graves, 2000), and as a result, how such issues compromised the communicative power of the words and language they used in their writing.

\section{Implications}

Based on this work, we see several implications for teachers and their classroom practice. First, teachers should use student writing as the context for helping students build their vocabulary and practice language use. Second, students should have the opportunity to 
write daily about what they are learning in content area classes, and not only in the language arts classroom. Content area readings and lessons expose students to the concepts and discourses unique to specific disciplines (e.g., deforestation or population increases, two topics that were explored by the student bloggers in our study). Opportunities to think and write about these and similar ideas will help young learners to study new concepts and acquire the vocabulary and syntax to describe them. The writing activities that are ideal for such explorations are report writing, "explaining to another" writing and "take a stand" writing.

Thirdly, teachers should engage student writers in genre analysis that will help them to learn about the linguistic and functional features of different genres of writing (e.g., persuasive argument versus exposition). A part of such instruction should include teaching specialized vocabulary used in different genres to communicate ideas to readers. Teachers should conduct genre analysis in either a whole-class or small group discussion format, with the teacher serving as the leader or having students lead their peers to facilitate such analysis. Genre models and specialized vocabulary lists can come from the content area material students read in their other classes or from exemplar writing produced by teachers, or other writers and commenters who are experts in the subject matter and who can also write effectively using specialized terminology in the genres under analysis.

Bamford and Krisco's (2003) book is a great resource that offers texts and activities that are ideal for reviewing with young writers the key conventions, syntax, vocabulary, and visual display features in nonfiction genres on topics from across content areas. The text also provides the learning tools to introduce young writers to discipline-based thinking and reasoning (Beck \& Jeffery, 2009) characteristic of the writing produced by scientists, historians, or literary critics and the discipline-based discourse (e.g., analytic exposition) that these scholars use to express their disciplinary thinking. We believe that genre analysis and genre writing should be taught both in writing classes and across the curriculum to prepare young writers for the demands of academic writing and the common core curriculum requirements.

Finally - and perhaps most importantly - teachers should provide students with a real audience with which to engage in written conversations about their learning. The audience might be their immediate peers or peers in other classes at the same or another school, parents or even other community members. As illustrated in this work, blogging can extend conversations to audiences far beyond the classroom and make writing an authentic endeavor for young writers. Teachers should take advantage of such a powerful tool in their writing classrooms to support their students' language study and vocabulary development. 


\section{References}

Andrews, R., \& Smith, A. (2011). Developing writers: Teaching and learning in the digital age. New York: Open University Press.

Applebee, A. N., \& Langer, J. A. (2011). A snapshot of writing instruction in middle schools and high schools. English Journal, 100(6), 14-27.

Bamford, R. A., \& Krisco, J. V. (2003). Making facts come alive: Choosing and using nonfiction literature K-8. Norwood, MA: Christopher Gordon Publishers.

Beck, S. W., \& Jeffery, J. V. (2009). Genre and thinking in academic writing tasks. Journal of Literacy Research, 41, 228-272.

Beck, I. L., Perfetti, C. A., \& McKeown, M. G. (1982). Effects of text construction and instructional procedures for teaching word meanings on comprehension and recall. Journal of Educational Psychology, 74, 506-521.

Bruffee, K. (1984). Collaborative learning and the "conversation of mankind." College English, $46(7), 635-652$.

Calkins, L. M. (1994). The art of teaching writing. Portsmouth, NH: Heinemann.

Cao, C., \& Guo, S. (2015). Genre analysis and advanced English teaching. Theory \& Practice in Language Studies, 5(12), 2613-2618.

Carlisle, J. F. (2010). Effects of instruction in morphological awareness on literacy achievement: An integrative review. Reading Research Quarterly, 45(4), 464-487.

Carlo, M. S., August, D., McLaughlin, B., Snow, C. E., Dressler, C., Lippman, D. N., ... White, C.E. (2004). Closing the gap: Addressing the vocabulary needs of English-language learners in bilingual and mainstream classrooms. Reading Research Quarterly, 39(2), 188-215.

Carter, J. B., \& Evensen, E. A. (2011). Super-powered word study. Gainesville, FL: Maupin House Publishing.

Chomsky, N. (1965). Aspects of the theory of syntax. Cambridge, MA: MIT Press.

Corbin, J. M., \& Strauss, A. L. (2008). Basics of qualitative research: Grounded theory procedures and techniques (3rd edition). Los Angeles, CA: Sage.

Creswell, J.W. (2007). Research design: Qualitative, quantitative, and mixed methods approaches (3rd Edition.). Thousand Oaks, CA: Sage.

Dalton, B., \& Smith, B. E. 2014). Teachers' lesson design as remix: Composing with internet resources and a smart authoring tool. In R. E. Ferdig \& K. E. Pytash (Eds.). Exploring multimodal composition and digital writing (pp.116-134). Hersey, PA: IGI Global.

Dunn, P. A., \& Lindblom, K. (2011). Grammar rants: How backstage tour of writing complaints can help students make informed, savvy choices about their writing. Portsmouth, $\mathrm{NH}$ : Heinemann \& Boyton/Cook.

Ede, L., \& Lunsford, A. (1984). Audience addressed/audience invoked: The role of audience in composition theory and pedagogy. College Composition and Communication, 35(2), 155-171.

Elbow, P. (1998). Writing with power: Techniques for mastering the writing process. (2nd Ed.). Oxford, UK: Oxford University Press.

Freeman, D. E., \& Freeman, Y. S. (2004). Essential linguistics: What you need to know to teach reading, ESL, spelling, phonics, and grammar. Portsmouth, $\mathrm{NH}$ : Heinemann.

Gee, J. P. (1990). Social linguistics and literacies: Ideology in discourses: Critical perspectives on literacy and education. London: Farmer Press. 
Goodwin, A.P., \& Ahn, S. (2010). A meta-analysis of morphological interventions: Effects on literacy achievement of children with literacy difficulties. Annals of Dyslexia, 60(2), 183208. doi:10.1007/s11881-010-0041-x.

Graham, S., Harris, K. R., \& Santangelo, T. (2015). Research-based writing practices and the common core: Meta-analysis and meta-synthesis. Elementary School Journal, 15(4), 498-522.

Graham, S. (2000). Should the natural learning approach replace spelling instruction? Journal of Educational Psychology, 92(2), 235-47.

Gilbert, J., \& Graham, S. (2010). Teaching writing to elementary students in grades 4-6: A national survey. The Elementary School Journal, 110(4), 494-518.

Graves, M. (2000). A vocabulary program to complement and bolster a middle-grade comprehension program. In B. Taylor, M. Graves, \& P. van den Broek (Eds.), Reading for meaning: Fostering comprehension in the middle grades. Newark, DE: International Reading Association.

Halliday, M. A. K. (1975). Learning how to mean. London: Edward Arnold.

Halliday, M. A. K. (1973). Explorations in the functions of language. London: Edward Arnold.

Harmon, M. R., \& Wilson, M. J. (2006). Beyond grammar: Language, power, and the classroom. New York, NY: Routledge.

Kame'enui, E. J., Carnine, D. W., \& Freschi, R. (1982). Effects of text construction and instructional procedures for teaching word meanings on comprehension and recall. Reading Research Quarterly, 17, 367-388.

Kieffer, M. J., \& Lesaux, N. K. (2010). Morphing into adolescents: Active word learning for English-Language Learners and their classmates in middle school. Journal of Adolescent \& Adult Literacy, 54(1), 47-56.

Kieffer, M. J., \& Lesaux, N. K. (2012). Effects of academic language instruction on relational and syntactic aspects of morphological awareness for sixth graders from linguistically diverse background. The Elementary School Journal, 112(3), 519-545.

Kirby, J.R.; Deacon, S.H.; Bowers, P.N.; Izenberg, L., Wade-Woolley, L., Parilla, R. (2012). Children's morphological awareness and reading ability. Reading and Writing 25, 389410. DOI 10.1007/s11145-010-9276-5

Kirby, D., Kirby, D. L., \& Liner, T. (2004). Inside out: Strategies for teaching writing, (3rd Ed.). Portsmouth, $\mathrm{NH}$ : Heinemann.

Kittle, P. (2008). Write beside them: Risk, voice, and clarity in high school writing. Portsmouth, $\mathrm{NH}$ : Heinemann.

Krashen, S. D. (1988). Second language acquisition and second language learning. Upper Saddle River, New Jersey, NJ: Prentice Hall.

Kulhavy, R. W. (1977). Feedback in written instruction. Review of Educational Research, 47(2), 211-232.

Kuo, L.J, \& Anderson, R. C. (2006). Morphological awareness and learning to read: A crosslanguage perspective. Educational Psychologist, 41(3), 161-180.

Lunsford, A., \& Ede, L. (2009). Among the audience: On audience in an age of new literacies. In M. E. Weiser, B.M. Fehler, \& A. M. González. Engaging audience: Writing in an age of new literacies (pp.42-73). Urbana, IL: NCTE.

Marulis, L. M., \& Neuman, S. B. (2010). The effects of vocabulary intervention on young 
children's word learning: A meta-analysis. Review of Educational Research, 80(3), 300335.

Pacheco, M. B., \& Goodwin, A. P. (2013). Putting two and two together: Middle school students' morphological problem-solving strategies for unknown words. Journal of Adolescent \& Adult Literacy, 56(7), 541-553.

Padak, N., Newton, E., Rasinki, T., \& Newton, R. M. (2008). Getting to the root of word study: Teaching Latin and Greek word roots in elementary and middle grades. In A.E. Farstrup \& S. J. Samuels (Eds.). What research has to say about vocabulary instruction (pp. 6-31). Newark, DE: International Reading Association.

Penrod, D. (2005). Composition in convergence: The impact of new media on writing assessment. Mehwah, NJ: Lawrence Erlbaum.

Seipel, B. E. (2011). The role of implicit learning in incidental vocabulary acquisition while reading. Unpublished Dissertation, University of Minnesota, MN.

Stahl, S. A., \& Fairbanks, M. M. (1986). The effects of vocabulary instruction. Review of Educational Research, 56 (1), 72-110.

Tomasello, M. (2005). Constructing a language: A usage-based theory of language acquisition. Cambridge, MA: Harvard University Press.

Vygotsky, L. (1978). Mind in Society. London: Harvard University Press.

Weaver, C. (Ed). (1998).Lessons to share on teaching grammar in context. Portsmouth, NH: Heinemann. 